International Journal of Multi Disipline Science (IJ-MDS)

e-ISSN: 2615-1707 DOI: http://dx.doi.org/10.26737/ij-mds.v1i1.436

International Journal of Multi Disipline Science (IJ-MDS) is licensed under

a Creative Commons Attribution-NonCommercial 4.0 International License.

\title{
Economic System Convergence in Globalization Era and Its Implication on Renewal and Economic Law in Indonesia
}

\author{
Purwanto $^{1}$, Charlyna S. Purba ${ }^{2}$ \\ Faculty of Law of Panca Bhakti University, Pontianak, Indonesia ${ }^{1,2}$ \\ purwantoupb@gmail.com
}

\begin{tabular}{ll}
\hline Keywords : & ABSTRACT \\
convergence, globalization, & Conflicts of interest between developed and developing \\
renewal, economic law & countries can not be avoided in economic globalization. In \\
& the fight, there is domination and hegemony of economic \\
& concentration by economic actors from developed \\
& countries. The convergence of an accommodative \\
economic system, which does not separate categorically & between the capitalistic and socialist market economies, \\
& needs to be considered in the reform of Indonesian \\
& economic law.
\end{tabular}

\section{INTRODUCTION}

Globalization wave (Anggito Abimanyu, 1996) especially trade sector has caused impacts in various fields, there is a tendency the apperance of the ends of nation state. This condition can not run without a norm and rule of law. Globalization demands on legal system changes, because it involves all aspects of life, i.e. economic, political, socio-cultural including aspects of crime. The impact of globalization is the rise of liberalization of trade and investment by developed countries to developing countries.

Certain regions had formed economic cooperation to anticipate the free trade era, likely Asia Pacific Economic Cooporation (APEC), European Union (UE) dan North American Free Trade Agreement (NAFTA). Besides, there are several forms of economic cooperation and trilateral trade, such economic growth triangle area: Singapura - Johor - Riau and Malaysia - Thailand - Indonesia (N. Rosyidah Rakhmawati, 2006).

Form of those cooperations were efforts for further optimizing the national and regional market potential. The main cooperation are free market and openness mechanism, both capital transfer (investment) and imported goods inflows. Each country tried to adjust the rule of law by deregulation sometimes break through the principle of possessed sovereignty, it raised the rule of law inconsistencies and contrary existed legal principles. This is done in order to participate in free trade.

Indonesia as a country in the Asia Pacific region should strive to prepare themselves and anticipate the possibilities related to economic and trade dynamics.

In this case, the law especially the law relating to the economy, plays an important role to support domestic economic activities conducted among the countries. For that purpose steps are needed to address the need to formulate economic laws through the maintenance, creation and renewal of the 
law, especially recently, when the country was still not free from economic crisis impact.

Progressive economic globalization, accommodation against the law can support is a responsive law model, more focused on practical-adaptive aspects (Zudan Arief Fakrulah, 2000). Its implementation will synergize/grow with social base of business development.

Globalization is world capitalism formation and trade liberalization system. Absolutely, this condition created cooperation relationship between strong state and developing country in various activities including law. Global changes and various trans-national activists emergences required adjustment through economic process restructuring from national to international.

Through economic globalization, can be ascertained strong country will win over a developing/weak country, there was an exclusion process or a weak disability against the strong country. Serious implications related to this free market is an open opportunity for economic actors of developed countries through transnational corporations to develope its investments in developing countries.

The role of the state seems increasingly elimininated in this free trade era, people will continue to be free to form a network of fellow business actors between countries/global (Victor Purba, 1999). The essence of increasing trade strength by business actors or individuals between countries (international trade) basically according to the trade philosophy that asserts fundamental freedom with this freedom, anyone should have the freedom to trade. This freedom should not be limited by the different religions, tribes, beliefs, legal systems and so on (Huala Adolf, 2002). It is also in line with the free market adherents that suppress the independence of commerce is natural right.

The rapid development in the free market, the market is finally filled with various types and variations of goods and/or services are generally similar and complementary products to one another. Diversification of products that are so vast and supported by technological advances and good infrastructure causes the flow of goods and/or service transactions increasingly widespread across the territory of a country. Consumers are ultimately faced with a choice of varied goods and/or services from both domestic and foreign products. These conditions, on the one hand can bring the benefits of the consumer, because consumers have the flexibility in buying quality goods at competitive prices to meet their needs.

Economic globalization with free market spirit always idealizes the market as an arena, in which all economic decisions and actions are carried out by individuals in the framework of voluntary movements of money, goods and services. The creation of free market conditions, greatly affect the human life as a whole, where the mindset, consumption patterns, to the pattern of a country's policy is determined by it.

The presence of economic globalization encourages and changes the legal configuration becomes increasingly complex. As transactions and cross-border communications become widespread, there is a need to create an accommodating transnational rules. The increasing expansion of private law regimes in the global arena is increasingly producing substantive laws that reduce state interference.

A convergence of an accommodative economic legal system, through a regulation and policy is absolutely necessary, in order to achieve economic and social efficiency. This is done in order to eliminate the rise of social problems, such as the high disparity between business actors, and the contrast between the rich and poor and so on.

Starting from the above background formulation, with the central theme of the convergence of the economic system in the era of globalization and its implemnetasinya to Indonesian economic law, so for that significant problem to be filed are:

a. Is there a conflict of interest between developed and developing countries in the era of globalization?

b. How is the influence of the convergence of Indonesia's economic system in the era of globalization and its implementation towards the renewal of economic law? 


\section{METHOD}

Given the scope and characteristics of broad economic laws, It occurs as a consequence of the rapid development of international economic, commercial, and business relationships, the interdiplinary approach is considered adequate. For that method used in this research is socio-legal method (Ronny Hanitijo Soemitro, 1988). This method according to Sulistyowati Irianto conducted by using the normative approach of critical and empirical qualitative study (Sulistyowati Irianto, 2009).

\section{THEORETICAL FRAMEWORK}

Globalization is essentially an effort to integrate the national economy into a capitalistic global economy. In it is a global power capable of pushing liberal and capitalistic economic norms to other countries, especially countries in the Third World. Through Convergence (Danrivanto Budhijanto, 2010) an accommodative economic system, absolutely necessary in order to realize economic and social efficiency, due to the high disparity between business actors, and the contrast between the rich and poor and so on. In the renewal of economic law in the future the substance not only inhibits the interests of the capitalistic market, but also accommodates the social market economy (Satjipto Rahardjo, 2000).

Economic globalization provides an opportunity for industrialized countries to expand their economic expansion and gain unlimited profit, but on the contrary globalization makes the position of poor countries more and more cornered by freely traffic freight, services and capital, thus shutting down the domestic economy. Conditions like this, in relations between developed countries and third world countries there is always a conflict of economic interests (Hikmahanto Juwana, 2001). Arief Hidayat (Arief Hidayat, no years) in that context affirms:

Globalization in an ungodly and non-directional way or pattern is now causing developing countries difficult to stand as high as the developed countries. This is due to the hidden power behind globalization (which is actually capitalism, which in its last development is neoliberalism) is nothing but the "policies and control" of developed countries.

Developing countries that are heavily dependent on foreign investment injections always have an impact on two opposite sides. The economy grows rapidly on the one hand, but creates an endemic vulnerability on the other. This vulnerability would be a tremendous disaster when foreign capital accumulated was recouped by investors, leaving only an economic crisis that led to permanent poverty, which Zain Mualana was an inherent part of an increasingly massive globalization process (Zain Maulana, 2010).

Ironically developing countries are often trapped by adopting patterns and models of development applied in a number of western countries. The progress of the western industrialized countries as shown by the economic growth rate, the high investment, the stability of currency values, and other technical indicators make the developing countries enchanted by the phenomenon.

\section{RESULT AND DISCUSSION}

1. Penetration Globalization: Developed Country to Developing Country

Economic globalization is realized through liberalization, where the highest value of human beings is the development and happiness of the individual (individualism). So, putting individual freedom is the highest score. Society is solely a means for individuals to achieve its goals. Society merely serves the individual. that the culture and welfare of society will advance if individual talents and labor are increasingly allowed to flourish freely. The state must protect the freedom of individuals and groups in society. His power should be strictly limited. In the economic field, the system of capitalism is based on the freedom to try and compete with each other. 
It is this excessive expectation that has dragged the developing country into a dangerous sphere of economic liberalization. In such circumstances the state becomes increasingly difficult to maintain an independent and autonomous economic policy. In addition, government intervention in the economic field is also becoming increasingly difficult and becomes an unpopular economic policy. Each country is faced with the pressure to adopt liberal economic norms and democracy. This happens according to Zain Mualana, because, the modernization standard found in the western world is considered as the only model that will create prosperity. In ethical development, the ways and objectives of development are as important as having equal significance. The right way or tool in driving the development process will determine the maximum development result (Zain Maulana, 2010).

The result is a way or instrument to be subordinate in a development process, so that the development targets must be achieved despite using unhealthy ways for the development of society and the country in the future. The success of materialistic development such as high economic growth, financial stability, trade balance, and stability of currency values. Indicators of substantially more substantial developmental successes such as equity of development, distribution of community welfare, to the development of the quality of human life and the environment become marginalized and even deliberately forgotten (Zain Maulana, 2010).

\section{Globalization Creates Addiction}

As a multidimensional phenomenon of globalization is happening in all aspects of life, resulting in a variety of diverse perceptions and definitions about it. Economic globalization is virtually impossible to separate from neo-liberalism, meaning talking about economic globalization is about talking about disseminating and implementing neoliberal economic concepts around the world (Francis Wahono, 2003). On the economic aspect, the movement of goods and services that are so free and increasing foreign investment has provoked an increase in the high economic dependence of the periphery to the central countries. This economic dependence, in turn, will form an unbalanced pattern of relations between countries. This imbalance is a manifestation of the domination and hegemony of rich countries over poor countries (H.M. Safi'I, 2009).

Globalization of the economy in construction to create the gap and dependence of each country on the economies of developed countries. The turn of the world economy which is controlled only by some countries that have the power of industry and large corporations, makes the dependence become more real. This dependence is not only evident to all the world's people, but has become rational, so the dominance behind that dependence is almost acceptable as a reality.

Dependency is considered normal and normal. Certainly if viewed from a critical perspective, dependence on foreigners is not better than creating independence. Economic growth is placed as the goal of the state, so that the above-mentioned means of development become legitimate to do and continue. High economic growth is an important achievement for each country, as long as it is done by maximizing the potential of the domestic economy actively and economic growth is placed in the right position as one of the development instruments to create welfare rather than vice versa as the ultimate goal of development. This pattern of development is basically the trigger of the onset of world economic crisis. The economic game of the financial sector and capital markets has created a fragile and fragile world economic order.

The free market economy essentially jeopardizes the economic and social fundamentals of developing countries. The liberalization process will corner the economies of developing countries that are still very fragile. Excessive confidence in economic globalization has blinded policy-makers awareness in many countries, thereby avoiding the process of economic globalization happening intensely.

The doctrine that grossness can only be realized through a free market economy has turned a blind eye to many countries that globalization does not necessarily produce prosperity, but globalization has the 
opportunity to create unprecedented gaps and poverty throughout the history of human life (Zain Maulana, 2010).

Economic globalization is not only dangerous because of its impact in creating poverty, but more than that of globalization is actually an ideological framework that is deliberately produced to create imperialism. Arief Hidayat (Arief Hidayat, no years) again remembers the negative impacts of globalization, he says:

Globalization does not always bring benefits to all people, even for things that are proven to produce benefits alone there is always a group of people, nation or country who are harmed. They are victims of globalization. Whether realized or not, global poverty, the loss of the right to education, malnutrition and so on are the impact of a world order that does not provide equal or balanced play space and a just place for the entire population of the world. Meanwhile, the increasingly limited availability of natural resources due to human exploitation and the prediction of the occurrence of disasters caused by climate change in the form of global warming or climate change has caused the concern of the entire world population, not only from poor countries but also industrialized countries, and this has triggered tensions and conflicts to fight for the remaining natural resources. Not to mention the problem of lack of water, food and energy.

The negative impacts of economic globalization above, of course, are very influential for poor and developing countries, which are generally not ready to accept economic globalization as the main road for the state in achieving prosperity, so that the process of globalization tends to hit the economic development in third world countries due to unfair free competition.

Although generally present negative impacts, but for the ready and strong state of the foundation, globalization has a positive impact, namely the creation of prosperity for the countries that are ready and able to take advantage of opportunities that arise in the global era, democratization, transfer of knowledge and technology, recognition and respect for Human rights and environmental preservation.

\section{Convergence of Domestic and Global Economic System in Economic Law Renewa}

a. Indonesia's Uniqueness and Failure of Rostow Growth Implementation

Indonesia as a part of the world community can not escape the flow of global transformation, but on the side as a sovereign state with various kepelbagiannya (pluralitik) must still exist and awake. Indeed Indonesia is very unique, the objective condition of Indonesia which consists of 17,667 large and small islands. The Indonesian archipelago is the most scattered country on earth with its marine territory much larger than its land. In terms of ethnicity and culture, Indonesia is also among the most heterogeneous countries in the world. In Indonesia there are more than 300 ethnic groups and 50 languages which are very different from each other, not to mention we include Chinese, Arab and Indian ancestors who have long and generated become Indonesian Citizens. Similarly in religious life almost all the major religions of the world exist in Indonesia.

Indonesia as a part of the world community can not escape the flow of global transformation, but on the side as a sovereign state with various kepelbagiannya (pluralitik) must still exist and awake. Indeed Indonesia is very unique, the objective condition of Indonesia which consists of 17,667 large and small islands. The Indonesian archipelago is the most scattered country on earth with its marine territory much larger than its land. In terms of ethnicity and culture, Indonesia is also among the most heterogeneous countries in the world. In Indonesia there are more than 300 ethnic groups and 50 languages which are very different from each other, not to mention we include Chinese, Arab and Indian ancestors who have long and generated become Indonesian Citizens. Similarly in religious life almost all the major religions of the world exist in Indonesia.

The macro description is not enough to describe Indonesia's pluralism. Because Indonesia is also very economically, socially and politically, namely: (1) The economic life varies from swidden field system to wetland system with regular irrigation system, and capital-intensive plantations. From hawkers to 
the modern giant factories; (2) the social system also varies greatly from remote small villages to large and developed metropolitan cities, from nomadic to settled and multi-layered societies, to multiple matrilineal, patrilineal and bilateral allegiances; (3) as well as the political system is varied and configurative. That is the problem of unity and diversity. Given that the whole (unity) can not completely present the plurality and its parts. Similarly, plurality and parts can not be summed up to cover the whole. Both the whole and its parts have their own structure, value and system and dynamics. Consequently that's why orientalists are often caught up to the inadequate concepts about the Indonesian society dubbed as a dualistic, paradoxical and antagonistic society (Eka Dharmaputra, 1987).

This uniqueness of Indonesia, positioning in the context of development certainly can not be done linearly, as happened to the development of society in Europe. For his theory Rostow, which mentions that development, as a process of evolution of travel from traditional to modern, and always run linear to the front. This thought then transformed into what he called the five stage scheme. The assumption is that all Western societies have experienced traditional and eventually become modern. The traditional human attitude, by Rostow, is considered a problem, and therefore must be solved through development. The first phase of this process is (i) the traditional society, (ii) the prerequisite society taking off, (iii) the society takes off, (iv) the maturation society of growth, (v) the aspired modern society, the industrial society, in it created hight mass consumption (H.M. Safi'I, 2009).

Development in the context of the above understanding requires accumulative capital, the process of resource accumulation is effective and efficient gradually. The basis of this accumulation mechanism is required in the direction of perfect competition. However, it is proven that this plan can not be realized. In the course of Rostow's theory proved to be failed in Implementation in Indonesia, because the characteristic of Iindonesia pluralistic society, with the economic, political and socio-cultural disparity is still high, the linear development stage is not appropriately used as a reference, and proven to fail.

If traced to the strength of Rostow's growth theory during the New Order regime, bringing the consequences of legal existence is seen as an obstacle for the continuity of economic activity. At that time the law was not used as the foundation, guide, and enforcer of economic activities. The existence of the law was undermined by the rulers only to defend the New Order's economic politics devoted to the economic interests of developed countries and conglomerates and MNCs. However, after the monoter crisis that destroyed the economies of several countries in the world, they realized the importance of legal authority to create a conducive economic climate for the creation of prosperity.

\section{b. Convergence of Domestic and Global Economic System}

The government's commitment to the implementation of the fifth precept is really tested in this era of free and globalized competition. Bilateral and multilateral agreements within the framework of regional or global economic integration bind countries to new agreements and rules of the game, which often run into national interests. Not surprisingly, not a few of us accuse the capitalist system, free competition, and globalization as destroying the joints of the economy and the sovereignty of the state in realizing development for the welfare of the people.

The future economic system, the choice between the capitalist economic system, which cultes the free market or the Pancasila economic system, tends to side with the people's economy as has been affirmed in Article 331945 Constitution of Republic of Indonesia. It is not a categorical choice. According to Gregory and Stuart (Gregory et. al., 1992), the capitalist economic system is characterized, among other things, the control or ownership of the factors of production by the private sector, while the decision making which wants to be produced is in the hands of those who have these factors of production. Decisions are made, guided by market mechanisms that provide the necessary information while material incentives become the main motivators for economic actors. This system is often opposed to the system of socialism, which can be academically divided into 2 (two), namely market socialism and planned socialism. In a market socialism system the characteristics are the 
ownership of factors of production by the state and / or ownership collectively by the public. What decisions to produce has been decentralized and made based on needs that work based on market mechanisms. The motivation of economic actors is the material and moral incentives. Meanwhile, planned socialism characterized by state ownership of every factor of production. What to produce is tailored to the central planning and the economic actors are bound to implement what the center has planned. The motivation of economic actors is the material and moral incentives.

Pancasila economic system, has factors and characteristics that are not the same in connection with the above systems. Normatively, the provisions of Article 33 of 1945 Constitution of Republic of Indonesia often understood as an economic system worthy of use by the Indonesian nation. Article 33 paragraph (1) such as, states that the national economy is organized as a joint effort based on the principle of kinship. This principle can be viewed as a meaningful collective principle in the present context of brotherhood, humanism, and humanity. This means that the economy is not seen as a form of Western-style liberal system, but there are moral nuances and togetherness, as a reflection of social responsibility. The ideal form looks like a form of social market economic system, which is quite developed in Western European and Scandinavian countries. If scrutinized, then the whole norm in Article 33 of 1945 Constitution of Republic of Indonesia today it is not close to the idea of market, efficiency or globalization. Some terms are closer to social democratic ideals, for example, togetherness, sustainability, environmental insight, and independence. These values emerged as a reaction to the development of the global economy.

Establishing Pancasila's economic system as Indonesia's economic system is not easy, because for hundreds of years we have consumed liberal-quality economic legal system or serve the interests of capitalist countries. In fact, every product of economic laws and regulations has included Article 33 1945 Constitution of Republic of Indonesia as the legal basis, however, the articles contained in the law have not been consistently in line with the mandate of the Constitution. In fact, not infrequently the contents of the articles are contradictory. The great work ahead for legislators is how to be consistently capable of realizing the mandate of the constitution, for example in relation to, 'Earth and water and the natural wealth contained therein are controlled by the state and used for the greatest prosperity of the people' economic laws and regulations. With this assertion, it is hoped that the development of economic law can result in economic laws and regulations that not only serve the free market and account for the conglomerate or transnational corporations, but rather prioritize the principle of kinship for the people's prosperity (Adi Sulistiyono, no years).

So far the problem is more wrong in managing the momentum of globalization, even we tend to excessive. There are sequences in the stages of liberalization that we violate because the trap of dependence on foreign debt makes us not move on foreign pressure. One of them, liberalization of foreign exchange system and liberalization of trade and investment that is too fast and excessive. This makes the economy very open, while at the same time we are not setting up safety signs so it is vulnerable to any outside surprises.

Related to the protection of the interests of the people, it seems the state's commitment to the preservation of Article 331945 Constitution of Republic of Indonesia in the constitutional amendment. In fact, this article is reinforced. However, sometimes the problem is not in the presence or absence of constitutional mandate, but rather our commitment to make it happen. The recognition of the right to clothing, food, shelter, work, and decent living for every citizen is guaranteed by the constitution, but for a long time the constitution and the foundation of the state have become just a display. The practice of monopoly and the annexation of state assets controlling the livelihood of the public by the powerful, powerful-minded rulers has long been taking place. The principle of economic democracy that builds the development on the welfare goal as much as possible for the people is also still the level of ideals. 
c. Repositioning the Meaning of Globalization Against Local Law

Law is a basic component in a social order that serves to regulate the various types of interactions in society. Men have different interests. Humans will create laws to regulate their interests by agreeing to submit to state law, as well as by creating rules through private law. Or by pressing the state to draft, or adopt international law, customary law or applicable practice. The diversity of the law can not only be associated with different types of social order, but it is also linked to institutions in which the law serves as its liaison instrument. The fact that the law is plural is not new. Globalization has reinforced the dynamics of legal context.

In this regard, globalization can not be interpreted as a "one-way journey from West to East" through the spread of values and concepts of democracy, human rights and legal instruments. Globalization is also the spread and convergence of values, concepts, and laws from around the world to various parts of the world. Globalization is not only indicated by borderless state, but also borderless law. The laws of a certain region can penetrate into other unlimited territories. International and transnational law can penetrate into the territory of any country, even any local area at the grassroots. Or on the contrary, it is not impossible that local laws and principles are adopted in part or in whole into international law (Sulistyowati Irianto, 2009).

Looking at the global perspective it is demonstrated that the laws of the various degrees and corners of the world move into unlimited territories. That's where there is intense convergence, touch, interaction, contestation and mutual adoption among international, national and local laws. Therefore, the law keeps changing dynamically. In this case the creation of transnational and transnationalized law as a result of the occurrence of contact and adaptation, and the fulfillment of the interests of cooperation among (citizens) of the nation. In the present situation the analysis of legal pluralism in the early days is accepted again. Substantially, international, national, local law can no longer be viewed as a clear entity with clear and separate lines.

From a global perspective, legal pluralism becomes increasingly complex because of the presence of international and transnational law in certain social arenas, especially in the areas of humanitarian and business. Globalization can no longer be interpreted as a "one-way journey from the West to the East" through the spread of values and concepts of democracy, human rights and legal instruments. Globalization is also the spread of values, concepts, and laws from around the world to various parts of the world. Globalization is not only indicated by borderless state, but also borderless law. The laws of a certain region can penetrate into other unlimited territories. International and transnational law can penetrate into the territory of any country, even any local area at the grassroots. Or on the contrary, it is not impossible that local laws and principles are adopted in part or in whole into international law.

On the other hand, the encounter between the various legal systems can also be indicated by the existence of national laws that adopt the substance of the international treaty, especially in the humanitarian field. Interestingly, ideas about "justice" from different parts of the world, locally, can be part of an international legal instrument formulated jointly by many state delegations, and binding on those countries that ratify it. An example is the CEDAW Convention (Convention on the Elimination of All Forms of Discrimination against Women), which was adopted in 1979 and is now ratified by more than 180 countries. Perhaps not many are paying attention to what is recorded in the proceedings of the formulation proceedings. The idea of the formulation of article 14 of the CEDAW Convention on the prohibition of discrimination against rural women was born from an Indonesian representative, Mrs. Suwarni Saljo and representatives of the Indian delegation sitting next to him. This shows that globalization is not centrifugal, but also centripetal. The values of the political space and the local context can be adopted and become instruments of international law (Sulistyowati Irianto, 2009).

\section{Implementation in Economic Law Renewal}

With regard to the influence of the legal system in the making of economic legislation, according to Adi Sulistiyono at the present time the legal system in Indonesia is experiencing 'pull up and down'. 
The pull from below can be explained as follows. Even now common law dominate the legal tradition in Indonesia, but after the law of regional autonomy has been in place since 2001, the customary law system and Islamic legal system will also show its identity as values that should be reckoned for in some areas. In other words, the pull from below to the legal system in Indonesia is the emergence of the trend of 'micro nationalism of the legal system' in some regions of Indonesia (Adi Sulistiyono, no years).

In order to establish a national legal system, including the national economic law, the government sets out policies to utilize three legal systems living (living law) in Indonesia, namely the customary law system, Islam and the West as their raw materials. In the third era of the legal system is not convergent, often confronted as mutually hostile legal systems. The conditions of the conflict did not occur naturally but were deliberately created. Legal conflicts imply a fairly natural-sociocultural conflict of values. If there is a meeting between two or more value systems that are foreign to a society, it will always be done fairly. Because every society has absorptive power and adaptability to the conflicts of the value system. However, if the value system conflict was deliberately and sometimes artificially inflicted on the needs of colonial politics at the time, it was difficult to eliminate those conflicts satisfactorily. That is why we in Indonesia - in the stage of development of national economic law - are still in the search for a concept that will really support all the efforts and hopes of the nation that is building.

Although global powers successfully penetrate into Indonesian economic law. As a result, the rule of law in the economic sector that is used as the basis for economic development in Indonesia is much capitalistic. The capitalistic economic law is clearly contrary to 1945 Constitution of Republic of Indonesia, and hence must be reformed economic law, either convergence or harmonization to remain in accordance with the values of Pancasila and the 1945 Constitution of Republic of Indonesia without abandoning its ability to respond to global forces.

Related to that, Arief Sidharta (Bernand Arief Sidharta, 2000) proposed, the Indonesian national legal order must contain features:

1) Insight of nationality and insight of the archipelago

2) Able to accommodate the legal awareness of regional ethnic groups and religious beliefs;

3) As far as possible is written and unified;

4) Be rational that includes the rationality of efficiency, rationality, fairness, rationality of rules, and value rationality;

5) Procedural rules that ensure transparency, allowing a rational review of government decisionmaking processes;

6) Responsive to the development of community aspirations and expectations.

In line with the above proposal, it is the result of a seminar on national law at the Faculty of Law of the Islamic University of Indonesia, recommending that the national law under construction should be: 1). Based on Pancasila (philosophical) and 1945 Constitution of Republic of Indonesia; 2). Functioning to nurture, create social order, support the implementation of development, and secure the results of development.

\section{CONCLUSION AND RECOMMENDATION}

Based on the description of the above discussion, it can be conveyed conclusions and suggestions as follows:

1. Globalization is a multidimensional phenomenon that is happening in all aspects of life. The influence of economic globalization characterized by the emergence of a free market economy is a condition, in which the market occupies a central position and is not limited by territorial divisions. In this free market, idealizes the market as an arena, in which all economic decisions and actions are exercised by individuals in the voluntary movement of money, goods and services. The creation of free market conditions, greatly affect human life, ranging from: the mindset, consumption patterns, to the pattern of a country's policies 
2. In the era of globalization conflict of interest between developed and developing countries can not be inevitable. In the fight, there is domination and hegemony of economic concentration by economic actors from developed countries, through MNC to developing or poor countries has long been happening. Therefore, the convergence of an accommodative economic system, which does not separate categorically between capitalistic and socialist market economies, needs to be considered in the reform of Indonesian economic laws whose raw materials are derived from customary, Islamic and European law by staying responsive to the demands of global dynamics, which are Pancasila and 1945 Constitution of Republic of Indonesia.

\section{REFERENCES}

Abimanyu, Anggito. 1996. Ekonomi Indonesia Dalam era Globalisasi dan Liberalisasi:Suatu Fakta Empiris. Yogyakarta. Disampaikan sebagai Makalah Seminar Nasional PPSK.

Adolf, Huala. 2002. Hukum Ekonomi Internasional Suatu Pengantar. Jakarta: Rajawali Pers.

Dharmaputra, Eka. 1987. Pancasila: Identitas dan Modernitas, TinjauanEtis dan Budaya. Jakarta: BPK Gunung Mulia.

Fakrulah, Zudan Arief. 2000. Membangun Hukum Yang Berstruktur Sosial Indonesia Dalam Kancah Trends Globalisasi. Bandung: Penerbit PT. Citra Aditya Bakti.

Gregory et. al., 1992. Comparative Economic System. Fourth Edition, Boston: Houghton Mifflin Company.

Irianto, Sulistyowati. 2009. Metode Penelitian Hukum: Konstelasi dan Refleksi. Jakarta: Yayasan Obor Indonesia. 2009. Menuju Pembangunan Hukum Pro Keadilan Rakyat. Bandung: Yayasan Obor.

Mualana, Zain. 2010. Jerat Globalisasi Neoleberal; Ancaman bagi Negara Dunia Ketiga. Yogyakarta: Biak.

Purba, Victor. 1999. Peluang dan Tantangan Perdagangan Internasional Dalam Menghadapi Era Globalisasi. Disampaikan dalam Seminar: SESPANAS DEPRINDAG di Jakarta pada tanggal 1 Maret 1999.

Rahardjo, Satjipto. 2000. Pembangunan Hukum di Indonesia dalam Konteks Situasi Global. Yogyakarta: Muhamadiyah University Press.

Rakhmawati, N.Rosyidah. 2006. Hukum Ekonomi Internasional: Dalam Era Global. Malang: Bayumedia Publising.

Safi'I, H.M. 2009. Perencanaan Pembangunan Daerah (Kajian dan Aplikasi Rencana Pembangunan Jangka Menengah Daerah (RPJMD) di Kabupaten Hulu Sungai Selatan). Malang: Averroes Press.

Sidharta, Bernand Arief. 2000. Refleksi Tentang Struktur Ilmu Hukum: Sebuah Penelitian Tentang Fondasi Kefilsafatan Dan Sifat Keilmuan Ilmu Hukum. Bandung: Mandar Maju.

Soemitro, Ronny Hanitijo. 1988. Metodologi Penelitian Hukum dan Jurimetri, Bandung: Ghalia Indonesia.

Wahono, Francis. 2003. Neolberalisme. Yogyakarta: Cindelaras Pustaka Rakyat Cerdas.

Wojowasito, no years. Kamus Umum Lengkap Inggris Indonesia- Indonesia Inggris. Bandung: Penerbit Pengarang.

Adi Sulistiyono, Pembangunan Hukum Ekonomi Untuk Mendukung Pencapaian Visi Indonesia 2030, Pidato Jabatan Guru Besar Fakultas Hukum UNS.

Arief Hidayat, Bernegara Itu Tidak Mudah: Dalam Perspektif Hukum dan Politik, Pidato Pengukuhan Jabatan Guru Besar, Universitas Diponegoro Semarang.

Budhijanto, Danrivanto. 2010. Pentingnya Konvergensi Tatanan Hukum. Dikutip dari Kompas pada 23 Maret 2010.

Hikmahanto Juwana, 2001. Pidato Upacara Pengukuhan Sebagai Guru Besar Tetap Dalam Ilmu Hukum Internasional. Fakultas Hukum Universitas Indonesia: Depok pada 10 November 2001. 